\title{
Synopsis of the point-of-care ultrasound assessment for perioperative emergencies
}

\author{
Robert Chen, MD, FRCPC
}

Received: 14 November 2017/Revised: 22 August 2018/Accepted: 17 November 2018/Published online: 19 February 2019

(C) Canadian Anesthesiologists' Society 2019

\begin{abstract}
This module will introduce the concept of a point-of-care ultrasound (POCUS) examination for perioperative clinicians. A focused cardiac examination of ventricular filling and function is presented. An examination of the inferior vena cava is also reviewed as a tool to assess volume status. Finally, a brief examination of the lung and pleura is explored to aid the clinician in situations of patient hypoxia and difficult ventilation. Limited ultrasound cardiorespiratory examinations can be performed by non-cardiologists and non-radiologists. Information drawn from POCUS may aid in diagnosis and early rescue in perioperative care. Point-of-care ultrasound is likely to become standard of care for anesthesiologists in the same way that stethoscopy is presently.
\end{abstract}

\section{Objectives of the Continuing Professional Development module:}

After reading this module, the reader should be able to:

1. Describe a range of point-of-care ultrasound applications relevant to perioperative emergencies.

Electronic supplementary material The online version of this article (https://doi.org/10.1007/s12630-019-01303-0) contains supplementary material, which is available to authorized users.

R. Chen, MD, FRCPC ( $\varangle)$

Division of Cardiac Anesthesiology, Department of Anesthesiology and Pain Medicine, University of Ottawa, 40

Rue Ruskin St., Ottawa, ON K1Y 4W7, Canada

e-mail: rchen@ottawaheart.ca
2. Describe how to perform a focused cardiac ultrasound to answer binary questions regarding cardiac filling and function.

3. Describe how to perform a focused ultrasound examination of the inferior vena cava and its relevance in assessing a patient in shock.

4. Describe how to perform a limited ultrasound examination of the lungs and pleura to aid in the assessment of respiratory failure.

The stethoscope is often the feature that defines the medical doctor as did the head mirror only a few decades ago. Although the word arises from the Greek work stethos, meaning "thorax", and the Greek word skopion, meaning "to look in", it does not allow one to "see" into the chest. Ultrasound, however, truly allows one to look into the chest, quite unlike the traditional "stethophone" where one only listens to surrogates of physiology. ${ }^{1}$ This module offers a historical review of point-of-care ultrasound (POCUS) followed by proposed POCUS techniques for perioperative resuscitation. Although POCUS is most frequently taught with "hands on" invigilation, the module also offers some "how to" instructions that may be useful for the POCUS naïve.

Point-of-care ultrasound is an all-encompassing term that includes many different focused ultrasound examinations, often performed by the treating clinician to answer a specific clinical question. The use of POCUS in anesthesia for vascular access ${ }^{2}$ and guided regional anesthesia ${ }^{3}$ is well established. The value of POCUS of the chest and abdomen in critical situations is also generally well accepted. For example, the newest American Heart Association Advanced Life Support guidelines recommend the use of ultrasound in cardiac arrest with pulseless electrical activity. ${ }^{4}$ In a 2015 
editorial, Yang stated that "For further improvement in the current anesthetic or perioperative mortality, timely diagnosis and rescue is key. Ultrasound is playing an increasingly important role in that context, especially in noncardiac surgery". 5

Urgent POCUS became widespread in the trauma arena through the development and dissemination of focused abdominal sonography in trauma (FAST). Abdominal imaging was taught such that, rather than seek anatomical precision and detail in scanning, the clinician sought to rule in or rule out specific abnormal findings using narrowly defined ultrasound targets: a positive scan identifying free fluid in the abdomen, pericardium, or pelvis indicated the need for emergent surgery in an unstable trauma patient, with bleeding being the top differential diagnosis. A negative FAST indicated that an alternate explanation of shock needed to be found. ${ }^{6}$ Focused abdominal sonography in trauma also included the concept of an "indeterminate scan" - i.e., if clinicians could not rapidly produce an image that met minimum diagnostic quality, they were not to continue trying to generate an image. The scan would add no new information and would not affect the resuscitation. ${ }^{7}$ In this context, the targeted scanning taught to surgeons was highly sensitive and specific. Studies suggest that after 20 invigilated scans (or less), a non-radiologist could become proficient. ${ }^{8}$ Emergency physicians noting the diagnostic value of FAST began to use POCUS for non-trauma indications with good results. A patient in shock with the appropriate pre-test probability of a specific finding - for example free fluid in the abdomen (shown by ultrasound), and a positive serum or urine pregnancy test - might be offered a more rapid diagnosis and potentially quicker access to care. 9,10 Since the introduction of FAST, there has been a steady increase in the use of POCUS in the emergency department for non-trauma indications. ${ }^{11,12}$

The operating room and postanesthetic care unit (PACU) are not unlike the trauma room. Rapid decision-making is required. The clinical situation is dynamic. Complex physiology is not unusual (for example, high central venous pressure $[\mathrm{CVP}]$ does not necessarily indicate adequate left heart filling). Many of these indications are relevant to anesthesiologists and the methods and language of FAST can be applied effectively to the perioperative environment: targeted exam, dichotomous questions (rule in, rule out), and the use of other clinical methods in the case of indeterminate exams.

\section{A practical approach to the perioperative POCUS exam}

Various imaging standards are used in the POCUS literature depending on the background of the instructors.
Those trained by radiologists will examine patients with the ultrasound probe's unidirectional marker held to the patient's head or to the patient's right corresponding to an image on the ultrasound machine with the marker displayed to the left of the screen. Cardiology based POCUS practitioners examine patients with the probe's maker pointed to the patient's left or to the patient's head and the ultrasound screen displays the marker on the right. The two standards generate mirror images of each other with the exception of the subcostal four-chamber view of the heart. Following a previously published schema in this journal, the cardiology standard is presented here. ${ }^{13,14}$ An anesthesia specific POCUS examination may serve to answer critical perioperative questions when physical examination findings do not point to an easy answer and when a delay in diagnosis may lead to further harm:

- Is there fluid or air in the pleural cavity? Is drainage needed?

- Is there fluid in the pericardial cavity? Is drainage needed?

- Is there inadequate cardiac filling?

- Is there evidence of cardiac pump failure?

\section{Transducer}

In the same way that there are general rules to driving an automobile, an ultrasound machine can be distilled to similar controls. The POCUS user need only identify the controls for depth of field and gain. Once the ultrasound probe touches the patient, the depth is adjusted to put the target in the centre of the ultrasound screen. The gain (or brightness) is adjusted so that fluids (such as blood) appear black and various tissues are well visible to the user. As the assessment of cardiac obstruction, filling, and function plays an important role in the assessment of shock perioperatively, the entire examination is done with a sector probe (also called a "phased array" or "cardiac" probe). Its smaller footprint allows visualization between ribs. The lower transmitted ultrasound frequency (compared with the probes used to guide percutaneous procedures) also allows greater depth of imaging.

\section{Image orientation}

When scanning, the initial probe placement is orthogonal to the plane of the skin and the probe is initially moved cephalo-caudad and lateral-medial (or anterior-posterior at the flank) to acquire the target image. The image is then further optimized through sweeping movements where the tip of the probe remains in the same place on the patient 
and the beam is moved through an arc as if the beam were the bristles of a broom. Rocking of the probe changes the angle of the beam in the same anatomic plane. Axial rotation of the probe is familiar to those switching between short axis and long axis of vessels or nerves for out-ofplane and in-plane needling techniques. Video 1 demonstrates these three movements sequentially in the heart.

\section{Focused cardiac ultrasound (FOCUS)}

Focused cardiac ultrasound is to the formal transthoracic echocardiogram (consisting of over a dozen ultrasonic views of the heart ${ }^{15}$ equivalent as to what FAST is to a complete ultrasound examination of the abdomen. In addition, cardiologists include Doppler ultrasound modes to examine valve function and to answer other hemodynamic questions. At the most basic, using four views compared with a cardiologist's complete cardiac ultrasound examination, FOCUS can be completed rapidly, adding important information to a patient's resuscitation. ${ }^{16}$ Ventricular filling may be inferred by diastolic size. Noting the difference in ventricular size between systole and diastole provides an assessment of systolic function. Obvious fluid around the heart raises the possibility of pericardial effusion and tamponade physiology.

\section{Parasternal FOCUS}

Many POCUS practitioners (e.g., internal medicine or critical care) interpret echocardiographic images using the "cardiology convention" where the unidirectional marker on the echocardiography probe (typically a ridge, dot, or light) is held either to the patient's head or to the patient's left, and that marker (usually a dot or letter near the apex of the sector scan) is displayed on the right hand side of the screen. The parasternal long axis scan begins quite high on the chest, starting as high as the second intercostal interspace just lateral to the left sternal border. The marker on the probe is pointed to the right shoulder tip (approximately in the ten-thirty position on an imaginary clock face on the patient's chest with the 12 o'clock position to the patient's head). Lung findings should be noted (see the section on lung POCUS below). The probe is then moved caudad (Fig. 1), interspace by interspace, until the heart is in view with the right ventricular outflow tract (RVOT), left ventricle (LV), left ventricular outflow tract (LVOT), and two left sided cardiac valves apparent (Video 2). The cardiac apex often falls just out of the echo sector to the left. The scanning sector should be deep enough to image the left pleura and the descending thoracic aorta in

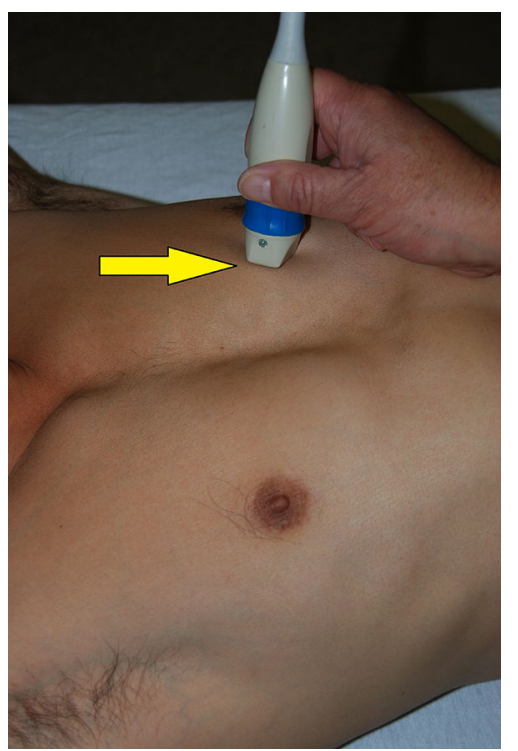

Fig. 1 Ultrasound probe placement (orientation and position) for acquiring a transthoracic parasternal long-axis view. The cephalocaudad movement is indicated by the yellow arrow). Note the probe marker (green dot)

Positionnement et orientation de la sonde d'échographie pour acquérir une fenêtre parasternale en axe longitudinal, ou grand axe. Le mouvement céphalocaudal est indiqué par la flèche jaune. Veuillez noter le marqueur de la sonde (point vert)

the far field. If only the right ventricle (RV) (the most superficial ventricle) or the LV without the aortic valve is visible, the operator should sweep the beam until the reference view is seen. Improving the image is a matter of understanding what is obstructing the view of the heart and where that obstruction is. Does the shadowing represent bone? Is the bone on the same side of the probe marker or the opposite side? How should the probe be moved (i.e., cephalo-caudad, lateral-medial) to avoid the obstruction? Are the lungs' distinct ultrasound characteristics observed? If the heart is partially obscured by lung, the same line of inquiry is followed. Where in the sector is the lung obscuring the image? How should the probe be moved to move the lung out of the image?

The hemodynamic questions answered in this single view are those of LV filling and systolic function. The RVOT is only a small portion of the RV. If the RVOT were noted to be larger than the LVOT or left atrium, RV dilation should be considered. In the same way that LV filling and function were determined in FOCUS, the same could be said of the RV in the parasternal long axis. The posterior pericardium is seen as a bright line immediately deep to the LV. Liquid effusions collect posteriorly in the supine patient. Lung findings and pleural effusions can be identified with increasing sector depth.

From the parasternal long axis view with the base of the LV chamber centred in the echocardiography sector, a 
disciplined $90^{\circ}$ clockwise rotation should result in imaging the heart in the short axis. The probe marker should face the left shoulder tip or the 1-2 o'clock position (Fig. 2). Sweeping the beam more towards the base or apex will allow the sonographer to find the reference plane: the LV short axis mid-papillary view. Rocking the probe within the same ultrasound plane centres the ultrasound image over the target (Video 3). Here, the pericardium is seen circumferentially. The RV shape and size in relation to the $\mathrm{LV}$ is noted. The LV filling and function can be estimated. Unique to this view are all three coronary artery perfusion territories - inferior wall in the far field = right coronary artery; anterior wall in the near field $=\mathrm{left}$ anterior descending artery; and the lateral wall opposite the intraventricular septum $=$ circumflex artery .

\section{Apical four-chamber FOCUS}

Once the parasternal window is well defined, the sonographer can use the parasternal long axis view to guide the probe to the cardiac apex. The probe is slid laterally towards the left within the same intercostal space until the probe is over the cardiac apex. The probe is then rotated clockwise until the marker points to the patient's left or the 3 o'clock position (Fig. 3). Sweeping anteriorly or posteriorly aligns the four-chamber view with the long axis of the ventricle (note: seeing the LVOT indicates that

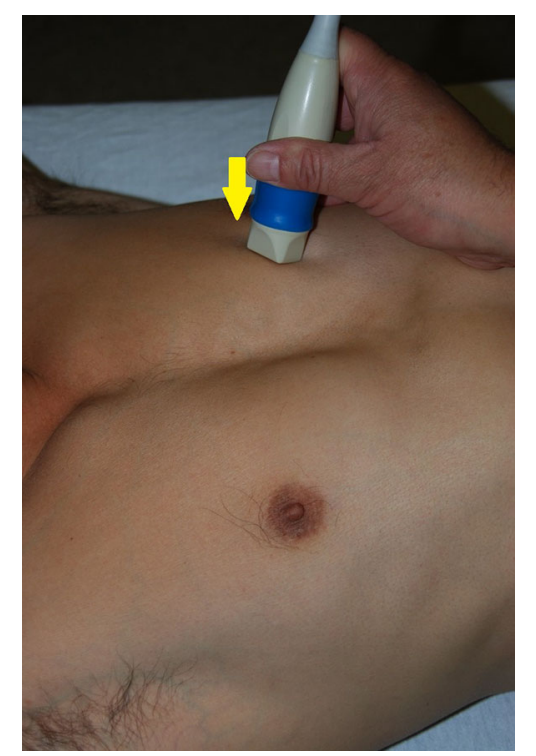

Fig. 2 Axial rotation in a clockwise direction is used to obtain a parasternal short-axis view. Note that new location of the probe marker (yellow arrow)

Une rotation axiale dans le sens des aiguilles d'une montre permet d'obtenir une vue parasternale en axe transverse. Veuillez noter la position du marqueur de la sonde (flèche jaune) the plane is too anterior, while seeing the coronary sinus means the plane is too posterior). Left ventricle and $\mathrm{RV}$ filling and function are assessed (Video 4). In this view, the $\mathrm{RV}$ is meant to be no more than two thirds of the LV's size in width. Reversal of that ratio occurs in $\mathrm{RV}$ failure conditions such as acute pulmonary embolism. Normal LV filling in an adult creates an end diastolic diameter of at least $4 \mathrm{~cm}$. Although the gold standard for quantifying ventricular function is volume-based ejection fraction, which is time consuming and require multiple views, visual estimation of chamber area change has proven an adequate and much simpler surrogate technique in the hands of noncardiologists. $^{17}$

\section{Subxiphoid/subcostal FOCUS with inferior vena cava (IVC)}

The probe is placed just caudad to the xiphisternum with the marker pointing to the patient's left, similar to the probe orientation of the apical four-chamber view. The ultrasound beam must pass just posterior to the sternum in a coronal plane. Direction of the beam subtly to the left of the midline (rocking) is necessary (Fig. 4). By identifying and examining the ventricles in this view, the

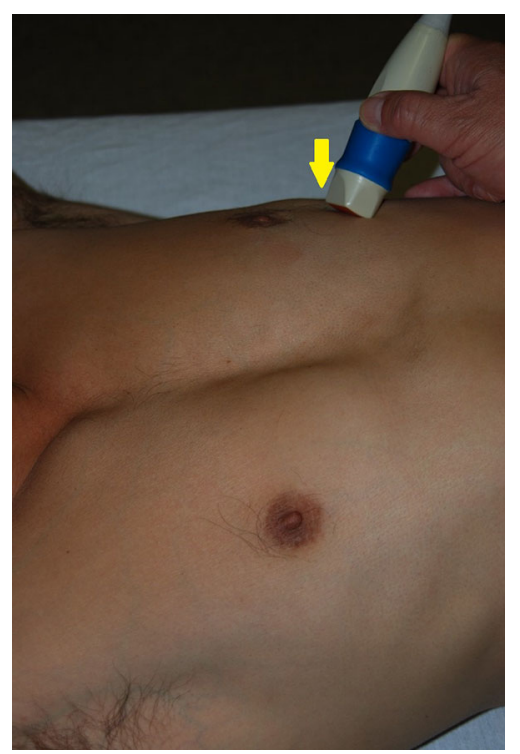

Fig. 3 Ultrasound probe position for acquiring an apical fourchamber view. The probe has been further rotated in a clockwise direction compared to parasternal short-axis view positioning. Note the position of the probe marker (yellow arrow) to the patient's left side

Position de la sonde pour obtenir une fenêtre apicale des quatre cavités. On effectue une rotation additionnelle de la sonde dans le sens des aiguilles d'une montre, par rapport à la vue parasternale en axe transverse. Veuillez noter la position du marqueur de la sonde (flèche jaune) vers la gauche du patient 
anesthesiologist gains additional insight into right ventricular (closest to the probe thus in the near field on the ultrasound display) and left ventricular (in the far field) filling and function. As with the apical view, in a subxiphoid four-chamber view, the RV is normally two-thirds the size of the LV (Video 5).

If the right atrium (RA) is centred in the ultrasound image (with a rocking motion), moving the probe to a near vertical position will sweep the beam caudally. Eventually, the RA disappears from view and is replaced by the IVC in its short axis. The same disciplined $90^{\circ}$ rotation of the probe, turning the marker towards the patient's head, images the IVC in the long axis (Video 6). Measured $2 \mathrm{~cm}$ from the RA, the IVC diameter and its collapsibility with spontaneous respiration can be used to estimate RA pressure. $^{18}$ A collapsed IVC would be seen with hypovolemia. An IVC that is greater than $2.5 \mathrm{~cm}$ and has no respiratory variability in diameter suggests a CVP in excess of $20 \mathrm{~cm}$. These measurements are valid in the spontaneously breathing patient. Positive pressure ventilation is known to decrease venous return and increase CVP, and the clinician must then re-interpret IVC sizes in those patients.

\section{Lung ultrasound}

Lung POCUS may be performed using the same cardiac probe as the FOCUS exam. ${ }^{19}$ The lung ultrasound findings most often reported in the literature can be reproduced using almost any transducer, including linear array probes and curvilinear probes, and useful findings may be seen even with using a transesophageal echocardiography probe! $!^{20}$ The probe is placed anywhere on the thorax

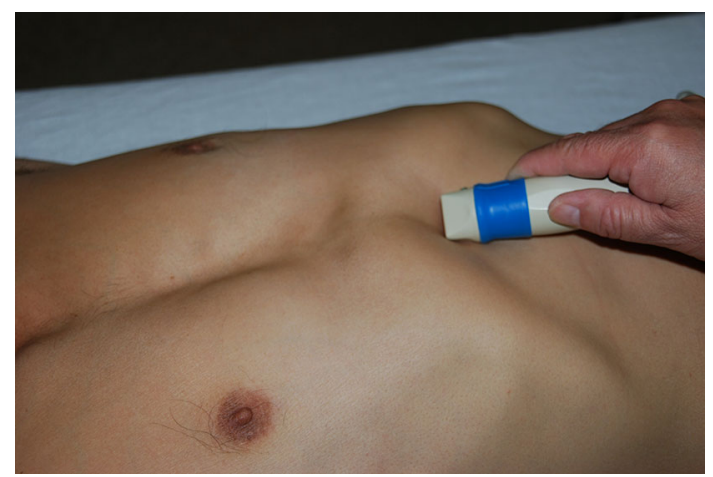

Fig. 4 Ultrasound probe position for acquiring the sub-costal/subxiphoid four-chamber view. Note that the position of the probe marker is similar to that of the apical four-chamber view

Position de la sonde pour acquérir une fenêtre sousxiphoïdienne/sous-costale. Veuillez noter que la position du marqueur de la sonde est semblable à celle de la fenêtre apicale des quatre cavités where lung findings are sought: in the supine patient, more consolidative findings and fluid are found posteriorly, whereas pleural air is usually found anteriorly. With the probe marker pointed cephalad, the image produced on the screen should be boarded by rib shadowing to each side. The findings of lung sliding and the pleural line, pleural reflections (Litchenstein's "A-lines") and comet tail artifacts (B-lines) define the presence of lung tissue (Fig. 5). Note that in FOCUS, these are the same lung artifacts that hide the heart and direct the practitioner to change the location of the sonographic window. An increasing number of B-lines is associated with increasing extravascular lung water. ${ }^{21}$ A "dry lung" has three B-lines or less in a single view whereas a "wet lung" has seven or more confluent B-lines. The absence of pleural movement or lung sliding suggests the absence of lung against the parietal pleura (either from pneumothorax or pleural effusion). An even, anechoic (dark) space deep to the pleura represents an effusion. When an effusion is identified, deepening the sector depth can help define it. The PACU patient with a chest $x$-ray demonstrating a lung "white-out" may produce very different ultrasound images. A simple effusion would appear as an even anechoic space. In this particular example, a hyperacute hemothorax with cellular elements is seen (Video 7). A complex effusion contains elements suggestive of chaotically moving fibrinous strands in an anechoic space (Video 8). By contrast, lung collapse (atelectasis), parenchymal hemorrhage, or an infectious consolidation create an ultrasound image of an organ whose texture is not unlike liver, an appearance known as hepatization (Video 9). The practitioner's pre-test probability added to the test (POCUS) would then lead to rank ordering of the differential diagnosis. Although each of these ultrasound images could result in an identical "white-out" on chest $x$ ray, the POCUS image would result in a very different treatment plan - i.e., catheter or thoracentesis $v s$ tube thoracostomy $v s$ bronchoscopy. Having imaged pleural collections, the operator can take advantage of the additional safety of marking the insertion point for a needle, catheter, or tube thoracostomy site using the ultrasound probe.

The table summarizes some of the most common uses of POCUS in anesthesiology. Real-time ultrasound guidance for central venous access has been published in guidelines for over a decade and is supported by specialty societies. It is reasonable to suggest that POCUS aided resuscitation may offer similar advantages. Beyond the techniques presented here, POCUS for airway assessment, ${ }^{22}$ full stomach assessment, ${ }^{23}$ and raised intra-cranial pressure (optic nerve sheath diameter ${ }^{24}$ and transcranial Doppler) ${ }^{25}$ may also have roles in perioperative medicine, but they are beyond the scope of this module. 
Fig. 5 Lung point-of-care ultrasound using a linear array probe. The normal lung findings including the pleural line and Alines (yellow arrows) can be seen. (see text for additional details)

Échographie POCUS d'un poumon normal avec l'aide d'une sonde linéaire. Veuillez noter la ligne pleurale et la "ligne A" de Lichtenstein (flèches jaunes). Voir le texte pour les détails

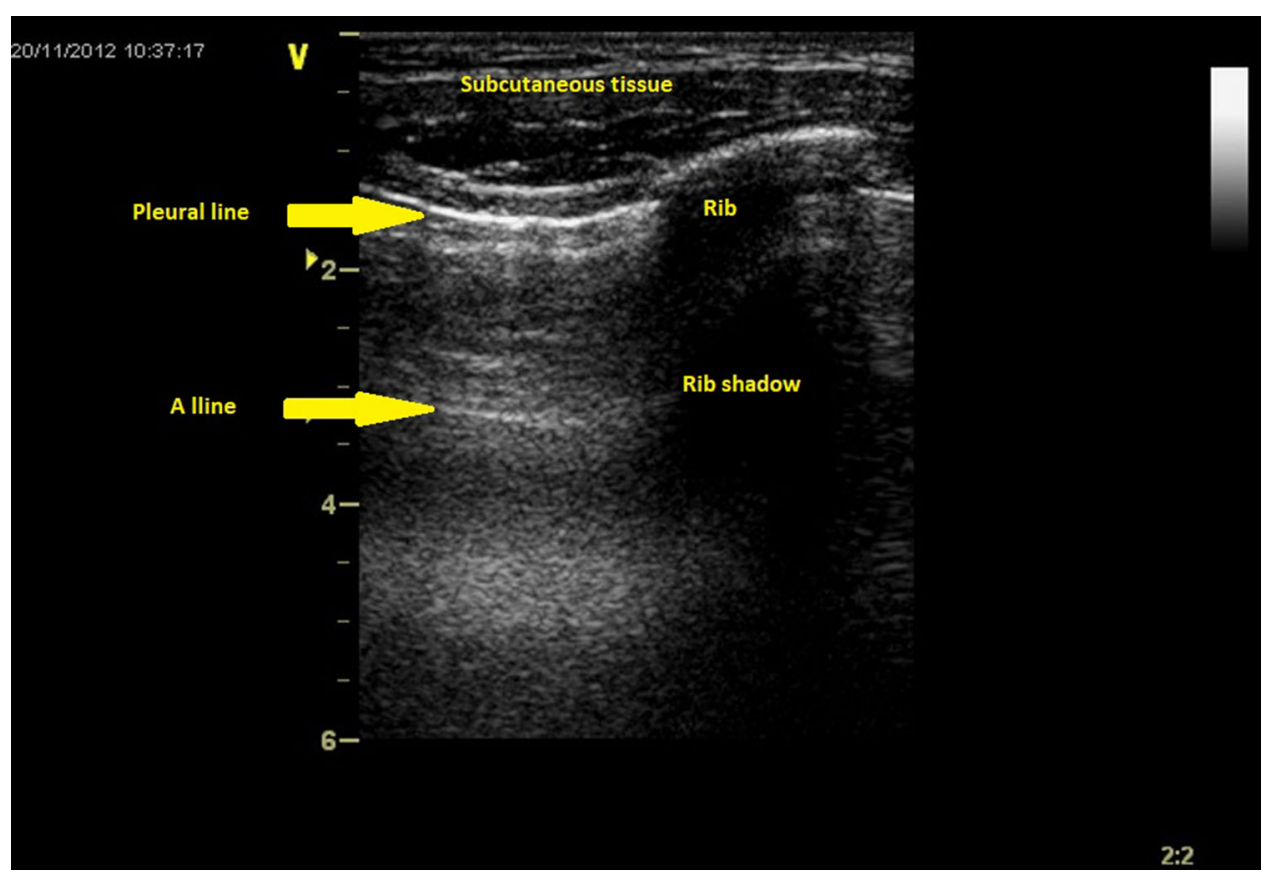

Table Some uses of point-of-care ultrasound in anesthesiology

Vascular access

Guided regional anesthesia

Cardiac

Lungs / pleura

Assessment of shock
Central venous catheterization

Peripherally inserted central venous catheter

Peripheral arterial and venous catheterization

In-plane and out-of-plane needle guidance

Ultrasound bony landmarking

Ultrasound assessment of complications

Perioperative transesophageal echocardiography

Focused cardiac ultrasound

Surface lung / pleura sonography

Transesophageal lung / pleura sonography

Inferior vena cava assessment of size and respiratory variability
Just as the cellular phone evolved from being appliancesized and later backpack-portable radio telephones, ultrasound machines have become smaller than their console predecessors. As the "stethophone" was in the past, cellular phone-sized POCUS platforms (digital stethoscopes) may well become the tool that defines the modern doctor. ${ }^{26}$

\section{Clinical case scenario}

A 75-yr-old patient fell off his bicycle and suffered an apparent isolated injury: a closed, right mid-femur fracture. Screening $x$-rays were negative for cervical spine or pelvic injury. A wide mediastinum noted on chest $x$-ray was attributed to his body habitus and antero-posterior imaging. He has been triaged for an emergent open reduction and internal fixation of his right femur. On initial evaluation, you note that he is obese and has a history of obstructive sleep apnea for which he uses a continuous positive airway pressure (CPAP) machine at home. He has type 2 diabetes managed with oral medication. He has attempted an exercise regime to improve his health. Surprisingly, he was fasting prior to going on a bicycle ride.

His vital signs recorded on the emergency record are: heart rate 100 beats per minute, blood pressure $140 / 90 \mathrm{mmHg}$, respiratory rate $30 / \mathrm{min}$, oxygen saturation $90 \%$ (on room air at admission). The patient describes $9 / 10$ pain in his leg. 
Instructions for completing the Continuing Professional Development (CPD) module:

1. Read the current article and the four references indicated in bold.

Go to: http://www.cas.ca/Members/CPD-Online and select the current module: Synopsis of the point-of-care ultrasound assessment for perioperative emergencies.

2. Answer the multiple-choice questions regarding the case scenario.

3. Once you have entered all of your answers, you will have access to experts' explanations for all the possible choices.

4. Participants may claim up to four hours of CPD under Section 3 of the CPD program of the Royal College of Physicians and Surgeons of Canada.

\section{Synthèse de l'évaluation par échographie au point d'intervention pour les urgences périopératoires}

Résumé Ce module introduira le concept d'examen échographique au point d'intervention (POCUS) pour les cliniciens chargés des soins périopératoires. Nous présentons un examen cardiaque orienté sur le remplissage et la fonction ventriculaires. L'examen de la veine cave inférieure est également abordé comme outil d'évaluation de la volémie. Nous explorerons pour terminer un bref examen des poumons et des plèvres pour aider le clinicien confronté à un patient hypoxique et dont la ventilation est difficile. Des examens cardiopulmonaires limités par échographie peuvent être pratiqués par des non-cardiologues et des non-radiologues. Les renseignements obtenus grâce à une échographie POCUS peuvent contribuer au diagnostic et à un traitement rapide en soins périopératoires. L'échographie au point d'intervention est susceptible de devenir la norme de soins pour les anesthésiologistes au même titre que l'utilisation du stéthoscope l'est actuellement.

\section{Objectifs du module de développement professionnel continu :}

Après avoir lu ce module, le lecteur doit pouvoir:
1. Décrire une série d'applications de l'échographie au point d'intervention pertinentes pour les urgences périopératoires.

2. Décrire comment effectuer une échographie orientée sur le cœur pour répondre à des questions binaires concernant le remplissage et la fonction cardiaques.

3. Décrire comment effectuer un examen échographique orienté sur la veine cave inférieure et sa pertinence pour l'évaluation d'un patient en état de choc.

4. Décrire comment effectuer un examen échographique limité des poumons et de la plèvre pour contribuer à l'évaluation d'une insuffisance respiratoire.

Le stéthoscope est souvent l'objet qui définit le médecin comme pouvait le faire le miroir frontal, il y a quelques dizaines d'années seulement. Bien que le terme provienne des mots grecs stethos, signifiant «thorax », et skopion, signifiant «voir dans », cet objet ne permet pas de voir dans la poitrine. En revanche, l'échographie nous permet vraiment de voir dans la poitrine, assez différemment du traditionnel «stéthophone » qui nous permet seulement d'entendre des succédanés physiologiques. ${ }^{1} \mathrm{Ce}$ module offre un aperçu historique de l'échographie au point d'intervention (POCUS) suivi par des suggestions de techniques d'échographie POCUS pour la ressuscitation périopératoire. Bien que l'échographie POCUS soit le plus souvent enseignée en conditions réelles sous supervision, le module offre également quelques consignes sur « comment faire » qui peuvent être utiles aux débutants dans la technique.

L'échographie au point d'intervention est un terme global qui recouvre de nombreux examens échographiques orientés, souvent réalisés par le médecin traitant qui cherche une réponse à un problème clinique particulier. L'utilisation de l'échographie POCUS en anesthésie pour l'accès vasculaire ${ }^{2}$ et l'anesthésie régionale guidée ${ }^{3}$ est bien établie. Sa valeur pour le thorax et l'abdomen dans des situations critiques est aussi généralement bien acceptée. Ainsi, les plus récentes lignes directrices ACLS (Advanced Cardiac Life Support) de l'American Heart Association recommandent l'utilisation de l'échographie dans l'arrêt cardiaque avec activité électrique sans pouls. ${ }^{4}$ Yang déclarait en 2015 dans un éditorial que «pour continuer à améliorer l'anesthésie actuelle ou réduire la mortalité périopératoire, un diagnostic et un traitement rapides sont primordiales. L'échographie joue un rôle de plus en plus important dans ce contexte, en particulier dans la chirurgie non cardiaque ». 5

L'échographie POCUS pratiquée en urgence est devenue courante dans le domaine de traumatologie avec le développement et la diffusion de la technique d'échographie abdominale orientée dans les traumas ou 
FAST (focused abdominal sonography in trauma). L'enseignement de l'imagerie abdominale était fait dans le but de permettre au clinicien de confirmer la présence ou non d'anomalies spécifiques en utilisant des fenêtres échographiques étroitement définies plutôt que de rechercher la précision anatomique et les détails au cours de l'examen : Un examen positif mettant en évidence la présence de liquide dans la cavité abdominale, le péricarde ou le pelvis constituait une indication d'intervention urgente pour un traumatisé instable chez lequel une hémorragie était le diagnostic suspecté numéro un. Une FAST négative indiquait qu'il fallait trouver une autre explication à l'état de choc. ${ }^{6}$ L'échographie abdominale orientée en traumatologie a également inclus le concept de « examen non concluant» où - si les cliniciens ne parvenaient pas à produire rapidement une image ayant une qualité diagnostique minimum, ils n'allaient pas continuer à essayer de générer une image. L'examen n'apporterait aucune information nouvelle et n'aurait pas de répercussion sur la ressuscitation. ${ }^{7}$ Dans cette perspective, l'examen ciblé enseigné aux chirurgiens était très sensible et spécifique. Les études suggèrent qu'après 20 examens supervisés (ou moins) un non-radiologue pouvait obtenir de bons résultats. ${ }^{8}$ Les urgentistes remarquant la valeur diagnostique de la FAST ont commencé à utiliser l'échographie POCUS dans des indications non traumatiques avec de bons résultats. Un patient en état de choc pour lequel il existe une bonne probabilité avant l'examen de faire une constatation spécifique : par exemple, la présence de liquide dans la cavité abdominale (visible à l'échographie) et un test de grossesse urinaire ou sérique positif pourraient aboutir à un diagnostic et possiblement à un accès aux soins plus rapide. ${ }^{9,10}$ Depuis l'introduction de la FAST, il y a eu une constante augmentation de l'utilisation de l'échographie POCUS pour des indications non traumatiques dans les services d'urgences. ${ }^{11,12}$

Une salle d'opération et les unités de soins post anesthésie (salles de réveil) ne sont pas très différentes des salles de traumatologie. Une prise de décision rapide est nécessaire. La situation clinique est une situation rapidement évolutive. Un état physiologique complexe n'est pas rare (par exemple, une pression veineuse centrale [PVC] élevée n'indique pas nécessairement un remplissage adéquat du cœur gauche). Beaucoup de ces indications concernent les anesthésiologistes et les méthodes ainsi que les termes utilisés par la FAST peuvent être utilisés efficacement dans un environnement périopératoire : Examen ciblé, questions binaires (confirmer/écarter le diagnostic) et utilisation d'autres méthodes cliniques dans le cas d'examens non concluants.

\section{Une approche pratique de l'échographie POCUS périopératoire}

Différentes normes d'imageries sont utilisées dans les publications sur l'échographie POCUS en fonction de la formation et de l'expérience des instructeurs. Ceux qui ont une formation de radiologue examineront les patients avec le marqueur unidirectionnel de la sonde d'échographie orienté vers la tête ou vers la droite du patient, correspondant à une image sur le moniteur d'échographie montrant le marqueur du côté gauche de l'écran. Les praticiens ayant une formation en cardiologie qui effectuent une échographie POCUS orienteront le marqueur de la sonde vers le côté gauche du patient et le marqueur s'affichera du côté droit de l'écran. Les deux normes génèrent des images en miroir de l'une par rapport à l'autre, à l'exception de la vue sous-costale des quatre cavités du cœur. Faisant suite à un schéma publié antérieurement dans ce Journal, la norme cardiologique sera présentée ici. ${ }^{13,14}$ Une échographie POCUS propre à l'anesthésiologie pourrait apporter une réponse aux questions périopératoires critiques quand les constatations de l'examen physique n'apportent pas une réponse simple et quand un retard de diagnostic pourrait se traduire par une aggravation du préjudice :

- Y a-t-il de l'air ou un liquide dans la cavité pleurale? Un drainage est-il nécessaire?

- Y a-t-il du liquide dans la cavité péricardique? Un drainage est-il nécessaire?

- Le remplissage cardiaque est-il insuffisant?

- Y a-t-il des évidences d'insuffisance de la pompe cardiaque?

\section{Transducteur}

De même qu'il existe des règles générales pour la conduite d'un véhicule, un appareil d'échographie peut être soumis à des contrôles de même nature. L'utilisateur d'un appareil d'échographie POCUS n'a besoin d'identifier que les commandes de profondeur de champ et de gain. Une fois que la sonde d'échographie est au contact du patient, la profondeur est réglée pour mettre la cible au centre de l'écran d'échographie. Le gain (ou luminosité) est ajusté de façon à ce que les liquides (tels que le sang) paraissent noirs et que les différents tissus soient bien visibles pour l'utilisateur. Comme l'évaluation d'une obstruction, du remplissage et du fonctionnement du cœur joue un rôle important dans l'évaluation d'un état de choc périopératoire, l'ensemble de l'examen est mené avec une sonde sectorielle (sector probe) (également appelée «phased array» [à décalage de phase] ou sonde 
« cardiaque »). Sa plus petite empreinte permet de visualiser entre les côtes. La fréquence d'ultrasons transmise plus faible (comparativement aux sondes utilisées pour guider les procédures percutanées) permet aussi une plus grande profondeur d'image.

\section{Orientation de l'image}

Pendant l'examen, le positionnement initial est perpendiculaire au plan de la peau et la sonde est d'abord déplacée dans le sens céphalocaudal et latéral-médial (ou antéro-postérieur au niveau des flancs) pour l'acquisition des images cibles. L'image est ensuite optimisée par des mouvements de balayage du faisceau dans lesquels l'extrémité de la sonde reste à la même place sur le patient tandis que le faisceau est déplacé selon un arc comme si le faisceau représentait les fibres d'un balai. Le balancement (Rocking) de la sonde change l'angle du faisceau dans le même plan anatomique. La rotation axiale de la sonde est bien connue de ceux qui passent de l'axe court à l'axe long des vaisseaux ou nerfs pour les techniques de piqûres dans et hors-plan. La vidéo $\mathrm{n}^{\circ} 1$ présente successivement ces trois mouvements sur le cœur.

\section{Échographie orientée sur le cœur (FOCUS)}

L'échographie orientée sur le cœur est à l'échocardiogramme transthoracique standard (comportant plus d'une douzaine d'images échographiques du cœur) ${ }^{15}$ ce qu'est la technique FAST à un examen échographique complet de l'abdomen. De plus, les cardiologues ajoutent des examens en mode Doppler pour étudier le fonctionnement valvulaire et répondre à d'autres questions d'hémodynamie. Dans sa version la plus simple, l'utilisation de quatre vues, par rapport à l'examen échographique complet d'un cardiologue, une échographie FOCUS peut être réalisée rapidement, ajoutant des informations importantes pour la ressuscitation d'un patient. ${ }^{16}$ Le remplissage ventriculaire peut être déduit de la taille en diastole. La différence de taille du ventricule entre la systole et la diastole procure une évaluation de la fonction systolique. La présence manifeste de fluide autour du cœur soulève la possibilité d'un épanchement péricardique et d'une physiologie de tamponnade.

\section{Échographie FOCUS parasternale}

De nombreux praticiens réalisant une échographie POCUS (par exemple en médecine interne ou en soins critiques) interprètent les images échocardiographiques en utilisant les «conventions cardiologiques » où le marqueur unidirectionnel de la sonde (habituellement une crête, un point ou une lumière) est tenu en direction de la tête ou de la gauche du patient, et ce marqueur (habituellement un point ou une lettre proche du sommet du secteur examiné) s'affiche du côté droit de l'écran. Le grand axe d'un examen parasternal débute assez haut sur le thorax, pratiquement au niveau du deuxième espace intercostal, juste en dehors du bord gauche du sternum. Sur la sonde, le marqueur est orienté vers la pointe de l'épaule droite (correspondant approximativement à la position de la petite aiguille à 10 h 30 sur une horloge imaginaire flanquée sur le thorax du patient, avec midi dirigé vers la tête du patient). Les constatations pulmonaires doivent être consignées (voir le chapitre sur l'échographie PoCUS des poumons plus loin). La sonde est alors déplacée en direction caudale (Fig. 1), d'espace intercostal en espace intercostal, jusqu'à ce que le cœur soit visible avec la chambre de chasse du ventricule droit (CCVD), le ventricule gauche (VG), la chambre de chasse du ventricule gauche (CCVG), et les deux valves cardiaques du côté gauche (Vidéo $\mathrm{n}^{\circ} 2$ ). La pointe du cœur se trouve souvent juste en dehors de la zone d'échographie, vers la gauche. Le secteur de balayage doit être suffisamment profond pour fournir des images de la plèvre gauche et de l'aorte thoracique descendante dans le champ lointain. Si seuls le ventricule droit (VD), le ventricule le plus superficiel, ou le VG sans la valve aortique sont visibles, l'opérateur doit basculer le faisceau jusqu'à ce qu'une image de référence apparaisse. L'amélioration de l'image impose de comprendre ce qui gêne la vue (quoi) et où (où) se trouve cet obstacle. L'ombrage représente-t-il un os? L'os est-il du même côté que le marqueur de la sonde ou du côté opposé? Comment la sonde doit-elle être déplacée (c'est-à-dire, dans le sens céphalo-caudal, ou latéralmédial) pour éviter l'obstruction? Les caractéristiques échographiques spécifiques des poumons sont-elles observées? On suivra le même axe d'analyse si le cœur est partiellement masqué par le poumon. Où le poumon masque-t-il l'image dans ce secteur? Comment doit-on déplacer la sonde pour sortir le poumon de l'image?

Les questions d'hémodynamie auxquelles cette vue unique répond sont le remplissage du VG et la fonction systolique. La CCVD n'est qu'une petite partie du VD. Si la CCVD semble plus grande que la CCVG ou l'oreillette gauche, il y a lieu d'envisager une dilatation du VD. De la même manière que le remplissage et le fonctionnement du VG ont été déterminés par l'échographie FOCUS, on peut dire la même chose du VD dans le grand axe parasternal. Le péricarde postérieur est vu sous forme d'une ligne brillante immédiatement plus profonde par rapport au VG. Les épanchements liquidiens se collectent en arrière (postérieurement) chez les patients en décubitus dorsal. 
Les constatations pulmonaires et les épanchements pleuraux peuvent être identifiés en augmentant la profondeur du secteur.

À partir de l'image de ce grand axe parasternal, la base du VG étant au centre du secteur échocardiographique, une rotation contrôlée de $90^{\circ}$ dans le sens des aiguilles d'une montre devrait fournir une image de l'axe transversal du cœur. Le marqueur de la sonde doit faire face à l'épaule gauche, indiquant sur l'horloge la position 1 ou 2 heures (Fig. 2). L'échographiste trouvera le plan de référence en basculant davantage le faisceau vers la base ou la pointe du cœur: vue de l'axe transversal du VG passant par les muscles papillaires. Le balancement de la sonde dans les mêmes plans échographiques centre l'image sur la cible (Vidéo $n^{\circ} 3$ ). Ici, le péricarde est vu dans sa circonférence. La forme du VD et sa taille par rapport à celle du VG sont consignées. Le remplissage et la fonction du VG peuvent être estimés. Cette vue est la seule permettant d'observer les trois territoires de perfusion des artères coronaires : la paroi inférieure en profondeur $=$ artère coronaire droite; la paroi antérieure dans le champ proximal $=$ artère interventriculaire antérieure; et la paroi latérale opposée au septum interventriculaire $=$ artère circonflexe.

\section{Échographie FOCUS apicale des quatre cavités cardiaques}

Une fois la fenêtre parasternale bien définie, l'échographiste peut utiliser la vue du grand axe parasternal pour guider la sonde vers la pointe du cœur. La sonde est glissée latéralement vers la gauche dans le même espace intercostal jusqu'à ce qu'elle se trouve audessus de la pointe du cœur. Elle est alors tournée dans le sens des aiguilles d'une montre pour que le marqueur soit dirigé vers la gauche du patient (position 3 heures) (Fig. 3). Une bascule vers l'avant ou vers l'arrière permet d'aligner la vue des quatre cavités avec le grand axe du ventricule (remarque : La vue de la chambre de chasse du VG indique que le plan est trop antérieur et la vue du sinus coronaire indique que le plan et trop postérieur). Le ventricule gauche, le remplissage et le fonctionnement du VD peuvent être évalués (Vidéo ${ }^{\circ} 4$ ). Dans cette vue, la largeur du VD ne doit pas mesurer plus des deux tiers de celle du VG. L'inversion de ce rapport est constatée en cas de défaillance du ventricule droit, par exemple en cas d'embolie pulmonaire aiguë. À la fin du remplissage normal du VG chez un adulte, son diamètre télédiastolique doit être d'au moins $4 \mathrm{~cm}$. Même si la référence pour la quantification de la fonction ventriculaire est la fraction d'éjection basée sur le volume, ce qui demande du temps et de multiples vues, l'estimation visuelle du changement de la surface cavitaire s'est avérée une technique de substitution adéquate et beaucoup plus simple entre les mains de non-cardiologues. ${ }^{17}$

\section{Échographie FOCUS sous-xiphoïdienne/sous-costale avec veine cave inférieure (VCI)}

La sonde est placée en position caudale immédiatement sous l'appendice xiphoïde, le marqueur pointant vers la gauche du patient dans une orientation semblable à celle de la vue apicale des quatre cavités. Le faisceau échographique doit passer juste derrière le sternum dans un plan coronal. Une très légère orientation du faisceau vers la ligne médiane (balancement [rocking]) est nécessaire (Fig. 4). En identifiant et examinant les ventricules dans cette vue, l'anesthésiologiste obtient un point de vue supplémentaire du remplissage et de la fonction du ventricule droit (le plus proche de la sonde et donc dans le champ proximal de l'affichage échographique) et du ventricule gauche (dans le champ distal). Comme dans la vue apicale, sous-xiphoïdienne, des quatre cavités, la taille du VD est normalement égale aux deux tiers de la taille du VG (Vidéo $\mathrm{n}^{\circ}$ 5).

Si l'oreillette droite (OD) est au centre de l'image échographique (avec un mouvement de balancement), le mouvement de la sonde vers une position quasi verticale va orienter le faisceau en direction caudale. L'OD finit par disparaître de la vue et est remplacée par la VCI dans son axe transversal court. La même rotation contrôlée de $90^{\circ}$ de la sonde, orientant le marqueur vers la tête du patient, fournit les images de la VCI dans son grand axe (Vidéo $\mathrm{n}^{\circ}$ 6). Mesurés à $2 \mathrm{~cm}$ de l'OD, le diamètre de la VCI et sa variation avec la respiration spontanée peuvent servir à estimer la pression de l'OD. ${ }^{18}$ Une VCI collabée pourrait être le signe d'une hypovolémie. Une VCI ayant un diamètre supérieur à $2,5 \mathrm{~cm}$ sans variation respiratoire suggère que la $\mathrm{PVC}$ est supérieure à $20 \mathrm{~cm}$. Ces mesures sont valides pour un patient respirant spontanément. On sait que la ventilation par pression positive diminue le retour veineux et augmente la PVC; le clinicien doit donc réinterpréter les dimensions de la VCI chez ces patients.

\section{Échographie pulmonaire}

L'échographie POCUS des poumons peut être réalisée avec la même sonde cardiaque que l'échographie FOCUS. ${ }^{19}$ Les constatations des échographies pulmonaires le plus souvent décrites dans les publications peuvent être reproduites en utilisant presque n'importe quelle sonde, y compris les sondes linéaires et curvilignes; des constatations utiles peuvent même être obtenues avec une sonde d'échocardiographie transœsophagienne! ${ }^{20} \mathrm{La}$ sonde est 
placée en tout point du thorax où des résultats sont recherchés dans les poumons : Sur un patient en décubitus dorsal, les découvertes de consolidations et de liquides sont faites postérieurement, tandis que la présence d'air dans la plèvre est habituellement trouvée en antérieur. Le marqueur de la sonde étant orienté vers la tête, l'image apparaissant sur l'écran devrait être bordée de chaque côté par l'ombrage des côtes. Les constatations de glissement de poumon et de lignes pleurales, de réflexion pleurale (« lignes $\mathrm{A}$ » de Lichtenstein) et des artéfacts en queue de comète (« lignes $\mathrm{B} »)$ définissent la présence du tissu pulmonaire (Fig. 5). Notez qu'en cas d'échographie FOCUS, il s'agit des mêmes artéfacts pulmonaires qui masquent le poumon et amènent le praticien à changer l'emplacement de la fenêtre d'échographie. Une augmentation du nombre de lignes $\mathrm{B}$ est associée à l'augmentation de l'eau pulmonaire extravasculaire. ${ }^{21}$ Un «poumon sec » a trois lignes B ou moins dans une unique vue tandis qu' un «poumon humide » compte sept lignes B confluentes ou plus. L'absence de mouvement pleural ou de glissement pulmonaire suggère une absence du poumon contre la plèvre pariétale (que cela soit dû à un pneumothorax ou à un épanchement pleural). Une zone régulière non échogène (sombre) au niveau de la plèvre est le signe d'un épanchement. L'accroissement de la profondeur du secteur peut contribuer à identifier la nature d'un épanchement quand il est détecté. Le patient qui, en salle de réveil, a une radiographie de thorax montrant un poumon «blanc» peut avoir des images échographiques très différentes. Un épanchement simple se présenterait comme une zone anéchogène homogène. Dans cet exemple particulier (vidéo $\mathrm{n}^{\circ} 7$ ), on peut voir un hémothorax suraigu avec éléments cellulaires. Un épanchement complexe contient des éléments suggérant la présence d'amas fibrineux se déplaçant de façon chaotique dans espace anéchogène (vidéo $\mathrm{n}^{\circ}$ 8). En revanche, un poumon collabé (atélectasie), une hémorragie du parenchyme ou une consolidation infectieuse créent une image échographique d'un organe dont la texture rappelle celle du foie, un aspect connu sous le nom d'hépatisation (vidéo $\mathrm{n}^{\circ} 9$ ). Les hypothèses du médecin avant l'examen ajoutées à celui-ci (échographie POCUS) permettraient alors de classer par ordre de probabilité les différents diagnostics possibles. Bien que chacune de ces images échographiques puisse se traduire par une radiographie pulmonaire identique «blanche», l'image de l'échographie PoCUS déboucherait sur un plan de traitement très différent, c'est-à-dire une thoracocentèse contre thoracostomie avec drain contre bronchoscopie. En outre, en ayant des images des épanchements pleuraux, le praticien peut en tirer parti pour choisir avec une plus grande sécurité le point d'insertion d'une aiguille, d'un cathéter ou d'un tube de thoracostomie en utilisant la sonde d'échographie.

Le tableau résume quelques-unes des utilisations les plus courantes de l'échographie POCUS en anesthésiologie. Le guidage échographique en temps réel pour un accès veineux central a été publié dans les lignes directrices depuis plus d'une dizaine d'années et est soutenu par les sociétés de médecins spécialistes. Il est raisonnable de penser que la ressuscitation aidée par l'échographie POCUS peut offrir des avantages comparables. Au-delà des techniques présentées ici, l'échographie POCUS pour l'évaluation des voies respiratoires, ${ }^{22}$ l'évaluation complète de l'estomac ${ }^{23}$ et de l'augmentation de la pression intracrânienne (diamètre de la gaine du nerf optique ${ }^{24}$ et Doppler transcrânien $)^{25}$ peuvent également avoir leur place dans la médecine périopératoire, mais elles sortent du cadre de ce module.

Tout comme le téléphone cellulaire a évolué de la taille d'une machine puis de celle de radiotéléphones portables dans un sac à dos, les appareils d'échographie sont devenus plus petits que leurs prédécesseurs à consoles. Comme le «stétophone» du passé, les plateformes d'échographie POCUS de la taille d'un téléphone cellulaire (stéthoscopes numériques) pourraient bien devenir l'outil définissant le médecin moderne. ${ }^{26}$

Tableau Quelques utilisations de l'échographie au point d'intervention en anesthésiologie

Accès vasculaire

Anesthésie régionale guidée

Cardiologie

Poumons / plèvre

Évaluation d'un état de choc
Cathétérisme veineux central

Cathéter veineux central inséré en périphérie

Cathétérisme artériel et veineux périphérique

Guidage d'aiguille dans et hors plan

Repérage osseux échographique

Évaluation échographique des complications

Échocardiographie transœsophagienne périopératoire

Échographie orientée sur le cœur

Échographie de surface des poumons/de la plèvre

Échographie transœsophagienne des poumons/de la plèvre

Évaluation de la veine cave inférieure et variabilité en fonction de la respiration 


\section{Scénario de cas clinique}

Un patient âgé de 75 ans a fait une chute de vélo et présente apparemment une blessure isolée: Une fracture fermée de la diaphyse fémorale droite. Les radiographies de dépistage de la colonne cervicale et du bassin ont été négatives. Un médiastin élargi noté sur la radiographie $d u$ poumon a été attribué à sa morphologie et à la prise d'une image antéro-postérieure. Le triage l'a orienté pour une réduction ouverte et fixation interne de son fémur droit en urgence. À l'évaluation initiale, vous notez qu'il est obèse et qu'il a des antécédents d'apnée-hypopnée du sommeil pour laquelle il utilise chez lui un appareil respiratoire à pression positive continue (CPAP). Il a un diabète de type 2 géré avec médication orale. Il a tenté de suivre un programme d'activité physique pour améliorer sa santé. Curieusement, il était à jeun avant de partir faire un tour en bicyclette.

Ses constantes vitales consignées dans le dossier des urgences sont les suivantes: Fréquence cardiaque $100 \mathrm{bpm}$, tension artérielle $140 / 90 \mathrm{mmHg}$, fréquence respiratoire 30/min, saturation en oxygène $90 \%$ (en air ambiant à l'admission). Le patient décrit une douleur dans sa jambe à $9 / 10$.

\section{Directives pour compléter le module de développement professionnel continu (DPC) :}

1 Lisez l'article actuel ainsi que les quatre références imprimées en gras.

Allez à : http://www.cas.ca/Membres/modules-de-DPC et choisissez le module actuel : Synthèse de l'évaluation par échographie au point d'intervention pour les urgences périopératoires.

2 Répondez aux questions à choix multiple concernant le scénario du cas clinique.

3 Après avoir saisi toutes vos réponses, vous aurez accès aux explications des experts concernant tous les choix possibles.

4 Les participants peuvent réclamer jusqu'à quatre heures de DPC au titre de la section 3 du programme de DPC du Collège royal des médecins et chirurgiens du Canada.

Conflict of interest Dr. Chen is a member of CAE Healthcare speakers' bureau.

Editorial responsibility This submission was handled by Dr. Stéphane Lambert, CPD Editor, Canadian Journal of Anesthesia.
Conflit d'intérêts Le $\mathrm{D}^{\mathrm{r}}$ Chen est membre du bureau des conférenciers de CAE Healthcare.

Responsabilité éditoriale Cet article a été traité par le $\mathrm{D}^{\mathrm{r}}$ Stéphane Lambert, Éditeur pour le DPC, Journal canadien d'anesthésie.

\section{References}

1. Mulvagh SL, Bhagra A, Nelson BP, Narula J. Handheld ultrasound devices and the training conundrum: how to get to "seeing is believing". J Am Soc Echocardiogr 2014; 27: 310-3.

2. Weiner MM, Geldard P, Mittnacht AJ. Ultrasound-guided vascular access: a comprehensive review. J Cardiothorac Vasc Anesth 2013; 27: 345-60.

3. Perlas A. Evidence for the use of ultrasound in neuraxial blocks. Reg Anesth Pain Med 2010; 35(2 Suppl): S43-6.

4. Neumar RW, Otto CW, Link MS, et al. Part 8: adult advanced cardiovascular life support: 2010 American Heart Association Guidelines for Cardiopulmonary Resuscitation and Emergency Cardiovascular Care. Circulation 2010; 122(18 Suppl 3): S72967.

5. Yang $H$. Perioperative medicine: why do we care? Can J Anesth 2015; 62: 338-44.

6. McKenney MG, McKenney KL, Compton RP, et al. Can surgeons evaluate emergency ultrasound scans for blunt abdominal trauma? J Trauma 1998; 44: 649-53.

7. American College of Emergency Physicians. Emergency ultrasound guidelines. Ann Emerg Med 2009; 53: 550-70.

8. Salen PN, Melanson SW, Heller MB. The focused abdominal sonography for trauma (FAST) examination: considerations and recommendations for training physicians in the use of a new clinical tool. Acad Emerg Med 2000; 7: 162-8.

9. Durham B. Emergency medicine physicians saving time with ultrasound. Am J Emerg Med 1996; 14: 309-13.

10. Burnette $R E J r$, Butler $R C$. Ruptured ectopic pregnancy after elective termination of intrauterine pregnancy discovered by use of ultrasonography in the emergency department. Acad Emerg Med 2000; 7: 830-3.

11. Socransky S; Emergency Department Targeted Ultrasound Interest Group, Canadian Association of Emergency Physicians. Emergency department targeted ultrasound. update. CJEM 2006; 2006(8): 170-4.

12. Pace J, Arntfield R. Focused assessment with sonography in trauma: a review of concepts and considerations for anesthesiology. Can J Anesth 2018; 65: 360-70.

13. Denault A, Vegas A, Royse C. Bedside clinical and ultrasoundbased approaches to the management of hemodynamic instability - Part I: focus on the clinical approach: continuing professional development. Can J Anesth 2014; 61: 843-64.

14. Vegas A, Denault A, Royse C. A bedside clinical and ultrasoundbased approach to hemodynamic instability - Part II: bedside ultrasound in hemodynamic shock: continuing professional development. Can J Anesth 2014; 61: 1008-27.

15. Lang RM, Badano LP, Mor-Avi V, et al. Recommendations for cardiac chamber quantification by echocardiography in adults: an update from the American Society of Echocardiography and the European Association of Cardiovascular Imaging. J Am Soc Echocardiogr 2015; 28(1-39): e14. 
16. Denault AY, Langevin S, Lessard MR, Courval JF, Desjardins $G$. Transthoracic echocardiographic evaluation of the heart and great vessels. Can J Anesth 2018; 65: 449-72.

17. Hope MD, de la Pena E, Yang PC, Liang DH, McConnell MV, Rosenthal DN. A visual approach for the accurate determination of echocardiographic left ventricular ejection fraction by medical students. J Am Soc Echocardiogr 2003; 16: 824-31.

18. Kircher BJ, Himelman RB, Schiller NB. Noninvasive estimation of right atrial pressure from the inspiratory collapse of the inferior vena cava. Am J Cardiol 1990; 66: 493-6.

19. Goffi A, Kruisselbrink R, Volpicelli $G$. The sound of air: point-ofcare lung ultrasound in perioperative medicine. Can J Anesth 2018; 65: 399-416.

20. Cavayas YA, Girard $M$, Desjardins $G$, Denault AY. Transesophageal lung ultrasonography: a novel technique for investigating hypoxemia. Can J Anesth 2016; 63: 1266-76.

21. Pelosi $\boldsymbol{P}$, Corradi $\boldsymbol{F}$. Ultrasonography in the intensive care unit: looking at the world through colored glasses. Anesthesiology 2012; 117: 696-8.

22. You-Ten KE, Siddiqui N, Teoh WH, Kristensen MS. Point-of-care ultrasound (POCUS) of the upper airway. Can J Anesth 2018; 65: 473-84.
23. Perlas A, Chan VW, Lupu CM, Mitsakakis N, Hanbidge A. Ultrasound assessment of gastric content and volume. Anesthesiology 2009; 111: 82-9.

24. Geeraerts $T$, Launey $Y$, Martin L, et al. Ultrasonography of the optic nerve sheath may be useful for detecting raised intracranial pressure after severe brain injury. Intensive Care Med 2007; 33: 1704-11.

25. Rigamonti A, Ackery A, Baker AJ. Transcranial Doppler monitoring in subarachnoid hemorrhage: a critical tool in critical care. Can J Anesth 2008; 55: 112-23.

26. Mehta M, Jacobson T, Peters D, et al. Handheld ultrasound versus physical examination in patients referred for transthoracic echocardiography for a suspected cardiac condition. JACC Cardiovasc Imaging 2014; 7: 983-90.

Publisher's Note Springer Nature remains neutral with regard to jurisdictional claims in published maps and institutional affiliations. 